Accepted manuscript - postprint version. Final form is published in: Kurutos, A., Orehovec, I., Saftić, D., Horvat, L., Crnolatac, I., Piantanida, I., \& Deligeorgiev, T. (2018). Cell penetrating, mitochondria targeting multiply charged DABCO-cyanine dyes. Dyes and Pigments, 158, 517-525.

https://doi.org/10.1016/j.dyepig.2018.05.035

\title{
Cell penetrating, mitochondria targeting multiply charged DABCO-cyanine dyes
}

Atanas Kurutos ${ }^{\mathrm{a} \dagger}$, Iva Orehovec ${ }^{\mathrm{b} \dagger}$, Dijana Saftic ${ }^{\mathrm{b}}$, Lucija Horvat ${ }^{\mathrm{c}}$, Ivo Crnolatac ${ }^{\mathrm{b}^{*}}$, Ivo Piantanida $^{\mathrm{b}^{*}}$, Todor Deligeorgiev ${ }^{\mathrm{d}}$

${ }^{a}$ Institute of Organic Chemistry with Centre of Phytochemistry, Bulgarian Academy of Sciences, Acad. G. Bonchev str., bl. 9, 1113 Sofia, Bulgaria

${ }^{\mathrm{b}}$ Laboratory for Biomolecular Interactions and Spectroscopy, Division of Organic Chemistry and Biochemistry, Ruđer Bošković Institute, Bijenička c. 54, 10000 Zagreb, Croatia

${ }^{\mathrm{c}}$ Laboratory for Molecular Plant Biology and Biotechnology Division of Molecular Biology, Ruđer Bošković Institute, Bijenička c. 54, 10000 Zagreb, Croatia

${ }^{\mathrm{d}}$ Department of Pharmaceutical and Applied Organic Chemistry, Faculty of Chemistry, University of Sofia, 1164 Sofia, Bulgaria

\section{"corresponding author:}

E-mail: icrnolat@irb.hr; tel: +38514571326; fax: +38514680195

E-mail: pianta@irb.hr; tel: +38514571326; fax: +38514680195

${ }^{\dagger}$ Authors share equal contribution to the first position. 


\section{Introduction}

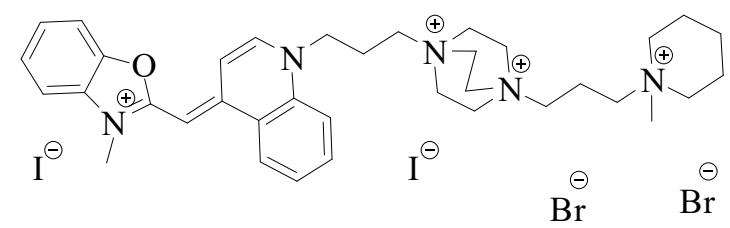

A

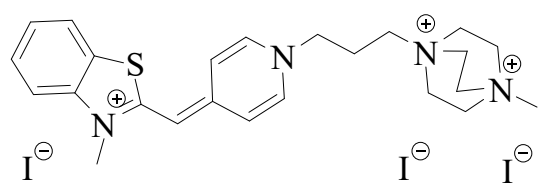

B2

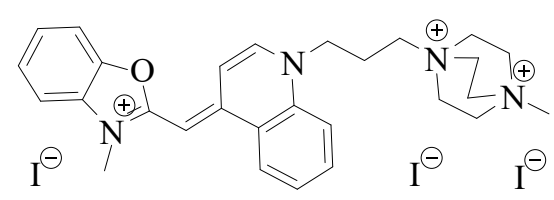

B1

Figure 1 Structures of the studied DABCO-cyanine dyes

In recent years, structurally diversified low molecular weight derivatives that are able to recognize and delineate tiny structural distinctions of DNA/RNA have attracted increasing interest, due to their various potential applications in many areas [1-5]. Therefore, the design and discovery of new low molecular weight molecules targeting DNA/RNA has been a subject of extensive studies. The underlying noncovalent interactions involved in these processes of specific recognition mainly combine few different binding modes, among which intercalation is highly represented [6]. Within this context, aromatic cationic dyes with the ability to penetrate through the cell membranes are of great interest. The tendency of such lipophilic cationic dyes to preferentially retain in the mitochondrial space makes them important group of fluorescent probes for the study of mitochondrial lipid bilayer, membranepermeability and specific staining of these organelles [7-9]. Shortcomings of such dyes are most commonly related to effects on mitochondrial respiration (electron transport chain 
Accepted manuscript - postprint version. Final form is published in: Kurutos, A., Orehovec, I., Saftić, D., Horvat, L., Crnolatac, I., Piantanida, I., \& Deligeorgiev, T. (2018). Cell penetrating, mitochondria targeting multiply charged DABCO-cyanine dyes. Dyes and Pigments, 158, 517-525.

https://doi.org/10.1016/j.dyepig.2018.05.035

activity), (photo)chemical stability (photobleaching), selectivity and high toxicity [10-14]. Although beneficial for the photo-chemotherapeutic applications, the singlet oxygen, $\mathrm{O}_{2}\left({ }^{1} \Delta_{\mathrm{g}}\right)$, as a reactive intermediate generated from energy transfer causes severe mitochondrial dysfunction [15]. Consequently, to overcome problems of probing the morphology and functions of mitochondria, the development of novel dyes with improved photochemical features is still a huge challenge. In that sense, 1,4-diazabicyclo[2.2.2]octane (DABCO) has been shown to be an efficient electron transfer quencher able to quench the singlet oxygen, stabilize fluorescence and reduce photobleaching effect [16]. Moreover, the DABCO-based species, with the ability to have two positive charges (with both nitrogen atoms reacted), have higher fixed charge density than other commonly used cationic antimicrobial agents. This increases their ability to specifically target mitochondria due to their high membrane potential $\Delta \psi_{\text {mito }}=150-180 \mathrm{mV}[8]$.

Encouraged by our previous research efforts in design of specific mitochondrial fluorescent probes based on benzoxazolium and benzothiazolium derived dicationic monomethine cyanine dyes [17-19], we have prepared new series of lipophilic cyanine dyes equipped with several cationic quaternary ammonium moieties. This was achieved by introducing DABCO within the structures. Furthermore, to investigate the influence of the additional cationic charges to the mitochondrial uptake, DABCO was quaternized with methyl group or alkyl piperidine cation. Spectroscopic and isothermal titration calorimetry studies as well as MTT assay and subcellular localization using confocal laser scanning microscopy revealed the presented dyes combine very low cytotoxicity with efficient cellular uptake and remarkable fluorescent marking of mitochondria.

\section{Materials and methods}

\subsection{Materials}


Accepted manuscript - postprint version. Final form is published in: Kurutos, A., Orehovec, I., Saftić, D., Horvat, L., Crnolatac, I., Piantanida, I., \& Deligeorgiev, T. (2018). Cell penetrating, mitochondria targeting multiply charged DABCO-cyanine dyes. Dyes and Pigments, 158, 517-525.

https://doi.org/10.1016/j.dyepig.2018.05.035

Unless otherwise stated, all starting materials and solvents required for the synthesis of the DABCO cyanine dyes were purchased from Sigma-Aldrich, Organica Feinchemie GmbH Wolfen, Fluka, Alfa-Aesar, TCI Europe, Deutero GmbH, and used without any further purification. The solvents used for the spectroscopic analyses were purchased form Macron Fine Chemicals TM. All other starting materials and solvents were commercial products of analytical grade and were used without further purification.

\subsection{Synthesis and spectroscopic analysis of the dyes}

\subsection{Analysis methods and equipment}

All products were characterized using various spectroscopic techniques. The progress of the reactions was monitored employing TLC (Merck F 254 silica gel; chloroform: methanol: acetic acid - 80:15:5). Recrystallization from methanol yielded analytical samples of the title cyanines. ${ }^{1} \mathrm{H}-\mathrm{NMR}$ and APT-NMR spectra of the compounds were recorded on a Brucker Avance III $500 \mathrm{MHz}$ instrument in $\mathrm{DMSO}_{-} \mathrm{d}_{6}$ at room temperature. Chemical shifts were reported in ppm in $\delta$-values with respect to tetramethylsilane (TMS) as an internal reference, or the corresponding peak of the deuterated solvent. Coupling constants $J_{H-H}$ were expressed in Hz. The structures of all intermediates were also evaluated on the target cyanine dyes. Melting point temperatures were evaluated on a Kofler bench and are uncorrected. Absorption and steady state fluorescence spectra of the unbound dyes were recorded in methanol solutions at room temperature, using 10-mm path-length quartz cuvettes on a Cecil Aurius CE 3021 UV-Vis spectrophotometer and Perkin Elmer LS45 fluorescence spectrometer (fixed slits $10-10 \mathrm{~nm})$ at room temperature.

\subsection{Synthetic approach to the DABCO monomethine cyanines and intermediate products}

\subsubsection{Preparation of intermediates $\mathbf{2 a - 2 c}$}


Accepted manuscript - postprint version. Final form is published in: Kurutos, A., Orehovec, I., Saftić, D., Horvat, L., Crnolatac, I., Piantanida, I., \& Deligeorgiev, T. (2018). Cell penetrating, mitochondria targeting multiply charged DABCO-cyanine dyes. Dyes and Pigments, 158, 517-525.

https://doi.org/10.1016/j.dyepig.2018.05.035

1,4-diazabicyclo[2.2.2] octane DABCO (1.12 g, $10 \mathrm{mmol})$ were suspended in $30 \mathrm{~mL}$ diethyl ether, and methyl iodide 1a $(0.94 \mathrm{~mL}, 15 \mathrm{mmol})$ or butyl iodide $\mathbf{1 b}(1.70 \mathrm{~mL}, 15 \mathrm{mmol})$ were added dropwise to it over 15 minutes with stirring. A white precipitate was formed, and the reaction mixture was further stirred for 30 minutes at room temperature and filtered under vacuum (Scheme 1). The products $\mathbf{2 a}$ and $\mathbf{2} \mathbf{b}$ were found to be highly hygroscopic, hence they were stored in a desiccator.

1-methyl-1,4-diazabicyclo[2.2.2]octan-1-ium iodide (2a); yield of crude product $=87 \%$ (white powder), m.p. $=.213-215{ }^{\circ} \mathrm{C}$, lit. m.p. $=220{ }^{\circ} \mathrm{C}[20-23] ;{ }^{1} \mathrm{H}-\mathrm{NMR}(500 \mathrm{MHz}$, DMSO$\left.\mathrm{d}_{6}, \delta / \mathrm{ppm}\right): 2.98\left(\mathrm{~s}, 3 \mathrm{H}, \mathrm{CH}_{3}-\mathrm{N}\right), 2.99-3.05\left(\mathrm{~m}, 6 \mathrm{H}, 3 \times \mathrm{CH}_{2}\right), 3.26-3.32\left(\mathrm{~m}, 6 \mathrm{H}, 3 \times \mathrm{CH}_{2}\right) ;{ }^{13} \mathrm{C}-$

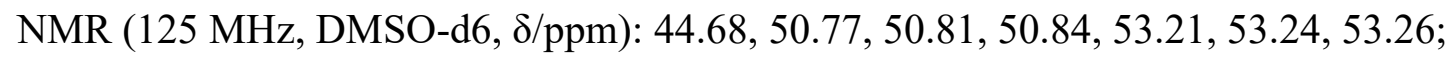

1-butyl-1,4-diazabicyclo[2.2.2] octan-1-ium iodide (2b) [21]; yield of crude product $=83 \%$ (white powder), m.p. $=36-37{ }^{\circ} \mathrm{C} ;{ }^{1} \mathrm{H}-\mathrm{NMR}\left(500 \mathrm{MHz}, \mathrm{DMSO}-\mathrm{d}_{6}, \delta / \mathrm{ppm}\right): 0.92$ (t, $3 \mathrm{H}, J_{H-H}$ 7.4, $\mathrm{CH}_{3}-\mathrm{CH}_{2}$ ), 1.30 (sext., $2 \mathrm{H}, \mathrm{J}_{\mathrm{H}-\mathrm{H}}$ 7.5, $\left.-\mathrm{CH}_{2}-\mathrm{CH}_{2}-\mathrm{CH}_{3}\right), 1.64\left(\mathrm{~m}, 2 \mathrm{H}, \mathrm{CH}_{2}\right), 3.02$ (t, $6 \mathrm{H}, J_{H-H}$ 7.7, $\left.3 \times \mathrm{CH}_{2}\right), 3.20\left(\mathrm{~m}, 2 \mathrm{H}, \mathrm{CH}_{2}\right), 3.29\left(\mathrm{t}, 6 \mathrm{H}, \mathrm{J}_{\mathrm{H}-\mathrm{H}} 7.1,3 \times \mathrm{CH}_{2}\right) ;{ }^{13} \mathrm{C}-\mathrm{NMR}(125 \mathrm{MHz}, \mathrm{DMSO}-$ $\mathrm{d} 6, \delta / \mathrm{ppm}): 13.5,19.25,23.02,44.64,51.42,51.45,51.47,62.96,62.98,63.01$;

1,4-diazabicyclo[2.2.2]octane 1 (5.61g, $50 \mathrm{mmol}$ ) and 1-(3-bromopropyl)-1-methylpiperidin1-ium bromide 1c (3.01 g, $10 \mathrm{mmol})$ [24] were dissolved in $50 \mathrm{~mL}$ methanol, and the reaction vessel was stored in dark place at room temperature for 1 week. Subsequently, the methyl alcohol was evaporated to $10-15 \mathrm{~mL}$ and $50 \mathrm{~mL}$ of acetone was added to it. The reaction mixture was placed in a freezer for 12 hours, after which the precipitated product $\mathbf{2 c}$ was filtered and stored in a desiccator (Scheme 1).

1-(3-(1-methylpiperidin-1-ium-1-yl)propyl)-1,4-diazabicyclo[2.2.2]octan-1-ium bromide (2c); yield $=79 \%$ - (white powder), m.p. $>300{ }^{\circ} \mathrm{C} ;{ }^{1} \mathrm{H}$ NMR $\left(\right.$ DMSO-d $\left._{6}, 500 \mathrm{MHz}\right) \delta /$ ppm: 1.53- 
Accepted manuscript - postprint version. Final form is published in: Kurutos, A., Orehovec, I., Saftić, D., Horvat, L., Crnolatac, I., Piantanida, I., \& Deligeorgiev, T. (2018). Cell penetrating, mitochondria targeting multiply charged DABCO-cyanine dyes. Dyes and Pigments, 158, 517-525.

https://doi.org/10.1016/j.dyepig.2018.05.035

$1.57\left(2 \mathrm{H}, \mathrm{m}, \mathrm{CH}_{2}\right), 1.79-1.85\left(4 \mathrm{H}, \mathrm{m}, 2 \times \mathrm{CH}_{2}\right), 2.22-2.28\left(2 \mathrm{H}, \mathrm{m}, \mathrm{CH}_{2}\right), 3.03-3.06(6 \mathrm{H}, \mathrm{m}$, $\left.3 \times \mathrm{CH}_{2}\right), 3.10\left(3 \mathrm{H}, \mathrm{s}, \mathrm{CH}_{3}-\mathrm{N}\right), 2.32-2.35\left(2 \mathrm{H}, \mathrm{m}, \mathrm{CH}_{2}\right), 3.39-3.46\left(12 \mathrm{H}, \mathrm{m}, 6 \times \mathrm{CH}_{2}\right) ;{ }^{13} \mathrm{C} \mathrm{NMR}$

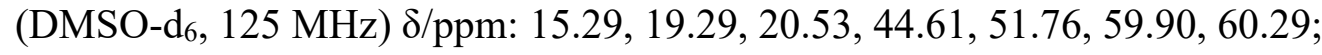

\subsubsection{Preparation of intermediates $\mathbf{3 a}, \mathbf{3 b}$}

Products 3a and $\mathbf{3 b}$ (Scheme 1) and N-quaternary intermediate chromophores required for their synthesis of the target polycationic DABCO cyanine dyes, were obtained via methods described in the literature [25-33].

\subsubsection{Synthesis of the tetracationic dye $\mathbf{A}$}

In a reaction vessel equipped with magnetic stirrer, (E)-2-((1-(3-iodopropyl)quinolin-4(1H)ylidene)methyl)-3-methylbenzo[d]oxazol-3-ium iodide 3a (1 g, $1.75 \mathrm{mmol})$ and 1-(3-(1methylpiperidin-1-ium-1-yl)propyl)-1,4-diazabicyclo[2.2.2]octan-1-ium bromide 3c ( $3.62 \mathrm{~g}$, $8.75 \mathrm{mmol}$ ) were dissolved in $20 \mathrm{~mL} \mathrm{2-methoxyethanol,} \mathrm{and} \mathrm{the} \mathrm{reaction} \mathrm{mixture} \mathrm{was} \mathrm{heated}$ at $135{ }^{\circ} \mathrm{C}$ for 3 hours with stirring. After cooling down to room temperature, $20 \mathrm{~mL}$ of methanol and $5 \mathrm{~mL}$ water were added to the crude product. Precipitated $\mathbf{A}$ dye was suction filtered and washed with diethyl ether (Scheme 1). The tetracationic product was purified by triple recrystallization from methanol.

\subsubsection{Synthesis of the tricationic B1, B2, and $\mathbf{C}$ cyanine dyes}

(E)-2-((1-(3-iodopropyl)quinolin-4(1H)-ylidene)methyl)-3-methylbenzo[d]oxazol-3-ium iodide 3a (1.14g, $2 \mathrm{mmol})$ or 2-((1-(3-iodopropyl)pyridin-4(1H)-ylidene)methyl)-3methylbenzo[d]thiazol-3-ium iodide $3 \mathbf{b}(1.07 \mathrm{~g}, 2 \mathrm{mmol})$ and mono-N-quaternary derivative of 1,4-Diazabicyclo[2.2.2] octane $\mathbf{2 a}(1.52 \mathrm{~g}, 6 \mathrm{mmol})$ or $\mathbf{2 b}(1.78 \mathrm{~g}, 6 \mathrm{mmol})$ were suspended in 5 $\mathrm{mL}$ 2-methoxyethanol, and the reaction mixture was heated to reflux for 40 minutes with stirring. After cooling down to room temperature, $3 \mathrm{~mL}$ of $\mathrm{N}, \mathrm{N}$-dimethylformamide were 
Accepted manuscript - postprint version. Final form is published in: Kurutos, A., Orehovec, I., Saftić, D., Horvat, L., Crnolatac, I., Piantanida, I., \& Deligeorgiev, T. (2018). Cell penetrating, mitochondria targeting multiply charged DABCO-cyanine dyes. Dyes and Pigments, 158, 517-525.

https://doi.org/10.1016/j.dyepig.2018.05.035

added, and the reaction vessel was placed in freezer for 2 hours. Precipitated DABCO dyes were suction filtered and washed with diethyl ether (Scheme 1). The tri-cationic products were purified by recrystallization from methanol. Chemical structures, yields and melting point temperatures are given in Table 1 .
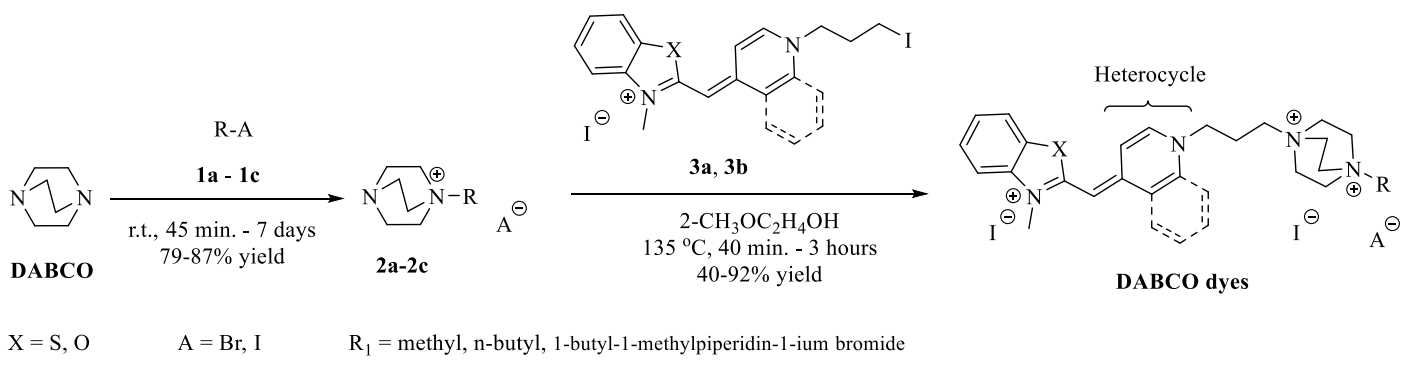

Scheme 1. Synthetic approach to the DABCO cyanine dyes.

Table 1. Chemical structures, yields and melting point temperatures of DABCO dyes.

\begin{tabular}{|c|c|c|c|c|c|c|}
\hline Dye & $\bar{X}$ & Heterocycle & $\mathbf{R}$ & $\mathbf{A}$ & Yield (\%) ${ }^{a}$ & m.p. $\left({ }^{\circ} \mathrm{C}\right)^{b}$ \\
\hline $\mathbf{A}$ & $\mathrm{O}$ & quinoline & & $\mathrm{Br}$ & 40 & $249-251$ \\
\hline B1 & $\mathrm{O}$ & quinoline & $\mathrm{CH}_{3}$ & I & 92 & $213-214$ \\
\hline B2 & $\mathrm{S}$ & pyridine & $\mathrm{CH}_{3}$ & I & 55 & $258-260$ \\
\hline C & $\mathrm{O}$ & quinoline & $\mathrm{C}_{4} \mathrm{C}_{9}$ & I & 87 & $210-212$ \\
\hline
\end{tabular}

${ }^{\mathrm{a}}$ yield of pure product after recrystallization. ${ }^{\mathrm{b}}$ all $\vartheta$ values are uncorrected.

(E)-1-(3-(4-((3-methylbenzo[d]oxazol-3-ium-2-yl)methylene)quinolin-1(4H)-yl)propyl)-4-(3(1-methylpiperidin-1-ium-1-yl)propyl)-1,4-diazabicyclo[2.2.2]octane-1,4-diium dibromide diiodide $(\mathbf{A})$; yield of crude product $=40 \%-($ orange solid $)$, m.p. $=249-251{ }^{\circ} \mathrm{C} ;{ }^{1} \mathrm{H}-\mathrm{NMR}$ (500 MHz, DMSO-d 6 , $\delta / \mathrm{ppm}): 1.50-1.63$ (m., 2H, $\mathrm{CH}_{2}$ ), 1.81 (m, 2H, $\mathrm{CH}_{2}$ ), 2.18-2.31 (m., 2H, $\left.\mathrm{CH}_{2}\right), 2.31-2.44\left(\mathrm{~m} ., 2 \mathrm{H}, \mathrm{CH}_{2}\right), 3.07\left(\mathrm{~s}, 3 \mathrm{H}, \mathrm{CH}_{3}-\mathrm{N}\right), 3.34-3.43\left(\mathrm{~m}, 6 \mathrm{H}, 3 \times \mathrm{CH}_{2}\right), 3.53-$ 3.64 (m., $\left.2 \mathrm{H}, \mathrm{CH}_{2}\right), 3.74-3.85$ (m., $\left.2 \mathrm{H}, \mathrm{CH}_{2}\right), 3.90\left(\mathrm{~s}, 3 \mathrm{H}, \mathrm{CH}_{3}-\mathrm{N}\right), 3.97$ (s, $\left.8 \mathrm{H}, 4 \times \mathrm{CH}_{2}\right), 4.67$ (t, 2H, $\left.J_{H-H} 6.9, C_{2}\right), 6.35(\mathrm{~s}, 1 \mathrm{H}, \mathrm{CH}), 7.42\left(\mathrm{td}, 1 \mathrm{H}, J_{H-H} 1.0,8.1, A r H\right), 7.52\left(\mathrm{td}, 1 \mathrm{H}, J_{H-H}\right.$ 
Accepted manuscript - postprint version. Final form is published in: Kurutos, A., Orehovec, I., Saftić, D., Horvat, L., Crnolatac, I., Piantanida, I., \& Deligeorgiev, T. (2018). Cell penetrating, mitochondria targeting multiply charged DABCO-cyanine dyes. Dyes and Pigments, 158, 517-525.

https://doi.org/10.1016/j.dyepig.2018.05.035

0.8, 7.8, $A r H), 7.69\left(\mathrm{~d}, 1 \mathrm{H}, J_{H-H} 7.8, A r H\right), 7.72-7.80(\mathrm{~m}, 1 \mathrm{H}, A r H), 7.83\left(\mathrm{~d}, 1 \mathrm{H}, J_{H-H} 7.9\right.$, $A r H), 7.97\left(\mathrm{~d}, 1 \mathrm{H}, J_{H-H} 7.4, A r H\right), 8.03\left(\mathrm{~d}, 1 \mathrm{H}, J_{H-H} 7.8, A r H\right), 8.23\left(\mathrm{~d}, 1 \mathrm{H}, J_{H-H} 8.8, A r H\right)$, $8.51\left(\mathrm{~d}, 1 \mathrm{H}, J_{H-H} 7.4, A r H\right), 8.82\left(\mathrm{~d}, 1 \mathrm{H}, J_{H-H} 7.9, A r H\right)$; APT-NMR(75 MHz, DMSO-d6, $\delta / \mathrm{ppm}): 16.06,19.74,20.99,31.11,39.15,39.43,39.71,39.99,40.27,40.55,40.83,48.60$, $51.19,60.88,75.03,109.60,111.41,118.39,123.87,125.00,127.01,131.82,133.93,137.66$, 143.97, 146.58, 150.57, 162.12; UV/VIS (methanol, $1 \times 10^{-5} \mathrm{~mol} \mathrm{dm}^{-3}$ ): $\lambda_{\max }=482 \mathrm{~nm}, \lambda_{f l}=$ $565 \mathrm{~nm}$;

(E)-1-methyl-4-(3-(4-((3-methylbenzo[d]oxazol-3-ium-2-yl)methylene)quinolin-1(4H)-

yl)propyl)-1,4-diazabicyclo[2.2.2]octane-1,4-diium iodide (B1); yield of crude product $=92$ $\%$ - (orange solid), m.p. $=213-214{ }^{\circ} \mathrm{C} ;{ }^{1} \mathrm{H}-\mathrm{NMR}\left(500 \mathrm{MHz}, \mathrm{DMSO}-\mathrm{d}_{6}, \delta / \mathrm{ppm}\right): 2.28-2.38(\mathrm{~m}$, $\left.2 \mathrm{H}, \mathrm{CH}_{2}\right), 3.27\left(\mathrm{~s}, 3 \mathrm{H}, \mathrm{CH}_{3}-\mathrm{N}\right), 3.67-3.73\left(\mathrm{~m}, 2 \mathrm{H}, \mathrm{CH}_{2}\right), 3.87\left(\mathrm{~s}, 10 \mathrm{H}, 5 \times \mathrm{CH}_{2}\right), 4.65\left(\mathrm{t}, 2 \mathrm{H}, \mathrm{J}_{\mathrm{H}-}\right.$ ${ }_{H}$ 7.2, $\left.\mathrm{CH}_{2}\right), 6.34(\mathrm{~s}, 1 \mathrm{H}, \mathrm{CH}), 7.40-7.45(\mathrm{~m}, 1 \mathrm{H}, \mathrm{ArH}), 7.48-7.54(\mathrm{~m}, 1 \mathrm{H}, A r H), 7.68(\mathrm{~d}, 1 \mathrm{H}, \mathrm{J}$ 7.9, $A r H), 7.72-7.78(\mathrm{~m}, 1 \mathrm{H}, A r H), 7.82\left(\mathrm{~d}, 1 \mathrm{H}, J_{H-H} 8.1, A r H\right), 7.97\left(\mathrm{~d}, 1 \mathrm{H}, J_{H-H} 7.3, A r H\right)$, 7.99-8.03 (m, 1H, $A r H), 8.17$ (d, 1H, $\left.J_{H-H} 8.8, A r H\right), 8.45$ (d, 1H, $\left.J_{H-H} 7.4, A r H\right), 8.81$ (d, 1H,

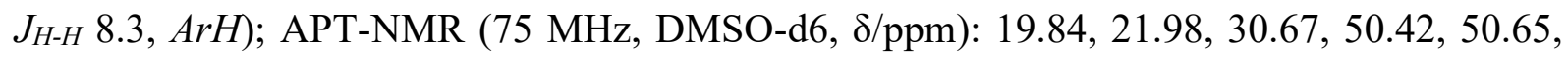
$52.43,60.51,74.58,109.14,110.94,117.86,123.44,124.57,126.11,126.33,126.56,129.78$, 131.37, 133.45, 137.15, 143.54, 146.12, 150.10, 161.66; UV/VIS (methanol, $1 \times 10^{-5} \mathrm{~mol} \mathrm{dm}^{-}$ $\left.{ }^{3}\right): \lambda_{\max }=482 \mathrm{~nm}, \lambda_{f l}=566 \mathrm{~nm}$;

1-methyl-4-(3-(4-((3-methylbenzo[d] thiazol-3-ium-2-yl)methylene)pyridin-1(4H)-yl)propyl)1,4-diazabicyclo[2.2.2]octane-1,4-diium iodide (B2); yield of crude product $=55 \%$ - (yellow solid), M.p. $=258-260{ }^{\circ} \mathrm{C} ;{ }^{1} \mathrm{H}-\mathrm{NMR}\left(500 \mathrm{MHz}, \mathrm{DMSO}-\mathrm{d}_{6}, \delta / \mathrm{ppm}\right): 2.25-2.41\left(\mathrm{~m}, 2 \mathrm{H}, \mathrm{CH}_{2}\right)$, $3.29\left(\mathrm{~m}, 7 \mathrm{H}, 2 \times \mathrm{CH}_{2}+\mathrm{CH}_{3}-\mathrm{N}\right), 3.50-3.63\left(\mathrm{~m}, 2 \mathrm{H}, \mathrm{CH}_{2}\right), 3.76\left(\mathrm{~s}, 3 \mathrm{H}, \mathrm{CH}_{3}-\mathrm{N}\right), 3.88(\mathrm{~s}, 8 \mathrm{H}$, $\left.4 \times \mathrm{CH}_{2}\right), 4.31\left(\mathrm{t}, 2 \mathrm{H}, J_{H-H} 7.0, \mathrm{CH}_{2}\right), 6.32(\mathrm{~s}, 1 \mathrm{H}, \mathrm{CH}), 7.30-7.38(\mathrm{~m}, 1 \mathrm{H}, \mathrm{ArH}), 7.45\left(\mathrm{~d}, J_{H-H}\right.$ 7.2, 2H, $2 \times A r H), 7.51-7.59(\mathrm{~m}, 1 \mathrm{H}, A r H), 7.65\left(\mathrm{~d}, 1 \mathrm{H}, J_{H-H} 8.0, A r H\right), 7.95\left(\mathrm{dd}, 1 \mathrm{H}, J_{H-H} 0.6\right.$, 
Accepted manuscript - postprint version. Final form is published in: Kurutos, A., Orehovec, I., Saftić, D., Horvat, L., Crnolatac, I., Piantanida, I., \& Deligeorgiev, T. (2018). Cell penetrating, mitochondria targeting multiply charged DABCO-cyanine dyes. Dyes and Pigments, 158, 517-525.

https://doi.org/10.1016/j.dyepig.2018.05.035

7.8, $A r H), 8.36\left(\mathrm{~d}, 1 \mathrm{H}, J_{H-H} 7.1, A r H\right)$; APT-NMR (75 MHz, DMSO-d6, $\left.\delta / \mathrm{ppm}\right):$ 23.27, $33.03,50.60,51.52,52.41,54.21,60.04,89.79,112.30,122.65,123.37,123.78,127.96$, $140.49,141.27,150.57,157.61$; UV/VIS (methanol, $1 \times 10^{-5} \mathrm{~mol} \mathrm{dm}^{-3}$ ): $\lambda_{\max }=453 \mathrm{~nm}, \lambda_{f l}=$ $487 \mathrm{~nm}$;

(E)-1-butyl-4-(3-(4-((3-methylbenzo[d]oxazol-3-ium-2-yl)methylene) quinolin-1(4H)yl)propyl)-1,4-diazabicyclo[2.2.2]octane-1,4-diium iodide $(\mathbf{C})$; yield of crude product $=87 \%$ - (orange solid), m.p. $=210-212{ }^{\circ} \mathrm{C} ;{ }^{1} \mathrm{H}-\mathrm{NMR}\left(500 \mathrm{MHz}, \mathrm{DMSO}-\mathrm{d}_{6}, \delta / \mathrm{ppm}\right): 0.94\left(\mathrm{t}, 3 \mathrm{H}, J_{H-H}\right.$ 7.3, $\mathrm{CH}_{3}-\mathrm{CH}_{2}$ ), 1.33 (quint., $\left.2 \mathrm{H}, J_{H-H} 7.4, \mathrm{CH}_{2}\right), 1.62-1.72\left(\mathrm{~m}, 2 \mathrm{H}, \mathrm{CH}_{2}\right), 2.27-2.35(\mathrm{~m}, 2 \mathrm{H}$, $\left.\mathrm{CH}_{2}\right), 3.47-3.53\left(\mathrm{~m}, 2 \mathrm{H}, \mathrm{CH}_{2}\right), 3.68-3.74\left(\mathrm{~m}, 2 \mathrm{H}, \mathrm{CH}_{2}\right), 3.85\left(\mathrm{~s}, 8 \mathrm{H}, 4 \times \mathrm{CH}_{2}\right), 3.90(\mathrm{~s}, 3 \mathrm{H}$, $\left.\mathrm{CH}_{3}-\mathrm{N}\right), 4.64\left(\mathrm{t}, 2 \mathrm{H}, J_{H-H} 6.8, \mathrm{CH}_{2}\right), 6.34(\mathrm{~s}, 1 \mathrm{H}, \mathrm{CH}), 7.40-7.45(\mathrm{~m}, 1 \mathrm{H}, \mathrm{ArH}), 7.50-7.55(\mathrm{~m}$, $1 \mathrm{H}, A r H), 7.69\left(\mathrm{~d}, 1 \mathrm{H}, J_{H-H} 7.8, A r H\right), 7.73-7.78(\mathrm{~m}, 1 \mathrm{H}, A r H), 7.82\left(\mathrm{~d}, 1 \mathrm{H}, J_{H-H} 8.0, A r H\right)$, $7.97\left(\mathrm{~d}, 1 \mathrm{H}, J_{H-H} 7.4, A r H\right), 8.02\left(\mathrm{~d}, 1 \mathrm{H}, J_{H-H} 7.3, A r H\right), 8.19\left(\mathrm{~d}, 1 \mathrm{H}, J_{H-H} 8.7, A r H\right), 8.45$ (d, $\left.1 \mathrm{H}, J_{H-H} 7.4, A r H\right), 8.82$ (d, 1H, $\left.J_{H-H} 8.4, A r H\right)$; APT-NMR (75 MHz, DMSO-d6, $\left.\delta / p p m\right):$ $13.47,18.99,22.0,23.31,30.65,50.41,50.75,60.47,63.24,74.56,109.14,110.96,117.88$, $123.41,124.54,126.08,126.29,126.29,126.54,131.35,133.44,137.18,143.50,146.10$, 150.10, 161.65; UV/VIS (methanol, $1 \times 10^{-5} \mathrm{~mol} \mathrm{dm}^{-3}$ ): $\lambda_{\max }=482 \mathrm{~nm}, \lambda_{f l}=565 \mathrm{~nm}$;

\subsection{Study of DNA/RNA interactions}

2.5.1 UV/Visible Spectrophotometry, circular dichroism (CD) and fluorescence spectroscopy

The UV/Vis spectra were recorded on a Varian Cary 100 Bio spectrophotometer; fluorescence spectra on a Varian Cary Eclipse fluorescence spectrophotometer and CD spectra were collected with a Jasco J-810 spectropolarimeter at $25{ }^{\circ} \mathrm{C}$ using $1 \mathrm{~cm}$ path quartz cuvettes. 
Accepted manuscript - postprint version. Final form is published in: Kurutos, A., Orehovec, I., Saftić, D., Horvat, L., Crnolatac, I., Piantanida, I., \& Deligeorgiev, T. (2018). Cell penetrating, mitochondria targeting multiply charged DABCO-cyanine dyes. Dyes and Pigments, 158, 517-525.

https://doi.org/10.1016/j.dyepig.2018.05.035

The polynucleotides: $\mathrm{p}(\mathrm{dAdT})_{2}, \mathrm{p}(\mathrm{dGdC})_{2}, \mathrm{p}(\mathrm{rA}-\mathrm{rU})$, and calf thymus (ct)-DNA (SigmaAldrich, St. Louis, USA) were dissolved in sodium cacodylate buffer, $I=0.05 \mathrm{~mol} \mathrm{dm}{ }^{-3}$, $\mathrm{pH}=7, c t$-DNA was additionally sonicated and filtered through a $0.45 \mu \mathrm{m}$ filter. Aqueous solutions of compounds were buffered to $\mathrm{pH}=7$ (sodium cacodylate buffer, $I=0.05 \mathrm{~mol} \mathrm{dm}^{-3}$ ). The polynucleotide concentration was determined as the concentration of phosphates by UV absorption [34]. Spectrophotometric titrations were performed at $\mathrm{pH}=7.0$ (sodium cacodylate buffer, $I=0.05 \mathrm{~mol} \mathrm{dm}^{-3}$ ) by adding portions of polynucleotide solution into the solution of the studied compound. Thermodynamic equilibrium is reached within a minute of polynucleotide addition to dye and 2-3 min incubation time was maintained through all the experiments.

In fluorescence spectroscopy experiments the excitation wavelength above $450 \mathrm{~nm}\left(\lambda_{\text {exc }}\right.$ $(\mathbf{A} ; \mathbf{B 1} ; \mathbf{C})=482 \mathrm{~nm} ; \lambda_{\text {exc }(\mathbf{B 2})}=452 \mathrm{~nm}$; excitation slits $\left.5 \mathrm{~nm}\right)$ was used to avoid the possible inner filter effect caused by increasing absorbance of the polynucleotide. The emission spectra were collected in the range $\lambda_{e m}=490-650 \mathrm{~nm}$ and $\lambda_{e m}=460-650 \mathrm{~nm}$ respectively, slits were set to $5 \mathrm{~nm}$ in both cases. The $\mathrm{CD}$ experiments were performed by adding aliquots of the aqueous solutions of the compounds into the buffered solution of polynucleotide. The titration data was processed using Scatchard equation by fitting fluorescence data with Origin 7.0 software package.

\subsubsection{Thermal denaturation experiments}

Thermal melting curves for $\mathrm{p}(\mathrm{dAdT})_{2}, \mathrm{p}(\mathrm{rA}-\mathrm{rU})$ and $c t$-DNA and their complexes with studied compounds were determined by following the change in the absorption at $260 \mathrm{~nm}$ as a function of temperature. The absorbance of the ligands was subtracted from each curve and the absorbance scale was normalized. $T_{\mathrm{m}}$ values are the midpoints of the transition curves, 
Accepted manuscript - postprint version. Final form is published in: Kurutos, A., Orehovec, I., Saftić, D., Horvat, L., Crnolatac, I., Piantanida, I., \& Deligeorgiev, T. (2018). Cell penetrating, mitochondria targeting multiply charged DABCO-cyanine dyes. Dyes and Pigments, 158, 517-525.

https://doi.org/10.1016/j.dyepig.2018.05.035

determined from the maximum of the first derivative and checked graphically by the tangent method. The $\Delta T_{\mathrm{m}}$ values were calculated subtracting $T \mathrm{~m}$ of the free nucleic acid from $T \mathrm{~m}$ of the complex. The $\Delta T_{\mathrm{m}}$ values (with the instrumental error $\pm 0.5^{\circ} \mathrm{C}$ ) reported are the average of at least duplicate measurements.

\subsubsection{Isothermal titration calorimetry (ITC)}

Titrations were performed on MicroCal VP-ITC (Malvern Panalytical, UK), the polynucleotide solutions (ct-DNA, $\mathrm{p}(\mathrm{dAdT})_{2}, \mathrm{p}(\mathrm{dGdC})_{2}$ prepared as in Section 2.1.1. The compounds were prepared from dimethyl sulfoxide (DMSO) stock solutions, dissolving them in $50 \mathrm{mM}$ sodium cacodylate buffer, $\mathrm{pH} 7.0$, resulting in $c=100 \times 10^{-6} \mathrm{~mol} \mathrm{dm}^{-3}$ of the dyes and $1 \%$ DMSO in the buffer. To avoid buffer mismatch, $1 \%$ DMSO was added to the polynucleotide solution. Origin 7.0 software, supplied by the manufacturer was used for data analysis. The reference cell was filled with ultrapure water. In the experiments, one aliquot of $2 \mu \mathrm{L}$ five aliquots of $5 \mu \mathrm{L}$ and 24 aliquots of $10 \mu \mathrm{L}$ of the compound $\mathbf{A}, \mathbf{B} 1, \mathbf{B 2}$, or $\mathbf{C}$ were injected from a rotating syringe $(220 \mathrm{rpm})$ into the isothermal cell, equilibrated at $25.0{ }^{\circ} \mathrm{C}$, containing $1.4406 \mathrm{~mL}$ of the polynucleotide $\left(c=30 \times 10^{-6} \mathrm{~mol} \mathrm{dm}^{-3}\right)$.

The spacing between each injection was in the range 240-300 s. The initial delay before the first injection was $2000 \mathrm{~s}$ in all experiments. All solutions used in ITC experiments were degassed prior to use under vacuum $(0.64 \mathrm{bar}, 10 \mathrm{~min})$ to eliminate air bubbles.

Microcalorimetric experiment directly gave three parameters: reaction enthalpy change $\left(\Delta_{r} H\right)$, binding constant $\left(K_{s}\right)$ and stoichiometric ratio $(N)$, number of dye molecules bound per polynucleotide. The value of $\Delta_{r} G$ was calculated from the binding constant $\left(\Delta_{r} G=-R T \ln K\right)$ and the reaction entropy change was calculated from the binding enthalpy and Gibbs energy $\left(\Delta_{\mathrm{r}} S=\right.$ $\left.\left(\Delta_{\mathrm{r}} H-\Delta_{\mathrm{r}} G\right) / T\right)$ 
Accepted manuscript - postprint version. Final form is published in: Kurutos, A., Orehovec, I., Saftić, D., Horvat, L., Crnolatac, I., Piantanida, I., \& Deligeorgiev, T. (2018). Cell penetrating, mitochondria targeting multiply charged DABCO-cyanine dyes. Dyes and Pigments, 158, 517-525.

https://doi.org/10.1016/j.dyepig.2018.05.035

\subsection{Biological assays}

\subsubsection{Subculturing of cells}

Adherent human cell lines (H460, non-small cell lung cancer) growing as monolayers on the surface of T-25 flasks (Sigma) were used. Dulbecco's Modified Eagle's medium (DMEM) (Sigma-Aldrich) containing amino acids and vitamins, as well as additional supplementary components were used for cell growth (complete medium). The primary cell culture media spent was removed and discarded from the culture flask. Cells were rinsed with $5 \mathrm{ml}$ of the pre-warmed phosphate-buffered saline (PBS) to remove protease inhibitors, and $0.1 \%$ trypsin solution was added to detach the cells from the substrate. Flask was further placed back in an incubator at $37^{\circ} \mathrm{C}$. The progress of the enzyme treatment was checked with an inverted phase contrast microscope. As the cells have rounded up and detach from the surface, $5 \mathrm{ml}$ of growth medium was added to the cell suspension and cells were vigorously washed. Suspended cells were further centrifuged $(100 \times \mathrm{g}$ for 5 minutes $)$ and trypsin containing medium was replaced with the fresh complete medium. Cells were further counted using Neubauer chamber under inverted phase contrast microscope. Considering the required dilutions, the amount of the cells in fresh medium was transferred to new flasks.

\subsubsection{Anti-proliferative activity evaluation by MTT assay}

The test was performed using H460 cells. Tested compounds, (A, B1, B2, and C) were prepared as stock solutions $\left(4 \times 10^{-2} \mathrm{~mol} \mathrm{dm}^{-3}\right)$ in DMSO, working solutions $\left(10^{-4}-10^{-8} \mathrm{~mol} \mathrm{dm}-\right.$ ${ }^{3}$ ) were prepared in DMEM medium accordingly. Cells were seeded in a 96 micro well flat bottom plates at the concentration $1 \times 10^{4}$ cells $/ 1$ and incubated overnight allowing them to attach to the plate surface, before exposure to the compounds. After $72 \mathrm{~h}$ incubation with tested compounds, growth medium was discarded and $5 \mathrm{mg} \mathrm{ml}^{-1}$ of MTT was added. After $4 \mathrm{~h}$ 
Accepted manuscript - postprint version. Final form is published in: Kurutos, A., Orehovec, I., Saftić, D., Horvat, L., Crnolatac, I., Piantanida, I., \& Deligeorgiev, T. (2018). Cell penetrating, mitochondria targeting multiply charged DABCO-cyanine dyes. Dyes and Pigments, 158, 517-525.

https://doi.org/10.1016/j.dyepig.2018.05.035

incubation at $37^{\circ} \mathrm{C}$ water insoluble MTT-formazan crystals were dissolved in DMSO. Absorbance was measured at $570 \mathrm{~nm}$ on a microplate reader (Multiskan EX, Thermo Fisher Scientific). Control cells were grown under the same conditions, with the absence of dyes. The experiments were performed in tetraplicates. The $\mathrm{IG}_{50}$ value, defined as compound concentration leading to cellular viability reduction by $50 \%$, compared to the control was calculated and used as a comparison parameter.

\subsubsection{Confocal Laser Scanning Microscopy (CLSM)}

Leica SP8X FLIM was used for fluorescence experiments in live-cell imaging (H460 cells). The images were processed in LAS X Leica Microsystems software packages. The cells were seeded into 4-chamber 35mm glass bottom petri dishes (Cellvis, Mountain View, USA) and incubated overnight allowing them to attach to the glass bottom of the petri dish. Three hours prior to cell imaging, the dyes were added to the medium $\left(c=10^{-6} \mathrm{~mol} \mathrm{dm}^{-3}\right)$.

\section{Results and Discussion}

\subsection{Synthesis and structural analysis of DABCO cyanine dyes}

A series of 1,4-diazabicyclo[2.2.2] octane derived unsymmetrical tri- and tetra-cationic cyanine dyes was obtained in moderate to high (40-92\%) yields by heating to reflux the two main components for 2-3 hours in a minimum amount of 2-methoxyethanol. The DABCO moieties were obtained by mono $\mathrm{N}$-quaternization using an excess of the corresponding alkylating agent 1a-1c (either 1.5 equivalents of methyl iodide / butyl iodide or 2-fold excess of 1-(3-bromopropyl)-1-methylpiperidin-1-ium bromide). The reactions were implemented at room temperature, yielding the products 2 a-2c $(79-87 \%$ yield). The former derivatives were subsequently attached to a monomethine dye scaffold containing a good leaving group-iodide, aiming to introduce multicationic nature on cyanine dyes. The chemical structures of the 1,4- 
Accepted manuscript - postprint version. Final form is published in: Kurutos, A., Orehovec, I., Saftić, D., Horvat, L., Crnolatac, I., Piantanida, I., \& Deligeorgiev, T. (2018). Cell penetrating, mitochondria targeting multiply charged DABCO-cyanine dyes. Dyes and Pigments, 158, 517-525.

https://doi.org/10.1016/j.dyepig.2018.05.035

diazabicyclo[2.2.2] octane derivatives and the target DABCO dyes, were elucidated by ${ }^{1} \mathrm{H}-$ NMR, ${ }^{13}$ C-NMR, APT-NMR spectroscopy and melting point temperatures. In the present work, our synthetic strategy was focused on the introduction of multiple positive charges on the main scaffold of oxazole yellow and thiazole orange derivatives in order to enhance the affinity towards polynucleotide structures. Another variation on the chromophore possessing a methyl group at para-position with respect to the $\mathrm{N}$-quaternary nitrogen atom (pyridine or quinoline moiety) was directed by both electronic and steric properties. Namely, the formation of $\mathrm{H}$-aggregates due to pi-stacking of the aromatic system, which can subsequently lead to alternation with respect to the binding mode (intercalation as monomer or accumulation in the hydrophobic grooves of the double stranded polynucleotide helixes as dimer). Hence, this alternation could potentially express selectivity towards certain nucleic acid sequences.

\subsection{Interactions of $\boldsymbol{A}, \boldsymbol{B} 1, \boldsymbol{B} 2$ and $\boldsymbol{C}$ dyes with $d s-D N A$ and $d s-R N A$.}

The UV/vis spectra of the dyes aqueous solutions are proportional to their concentration up to $0.01 \mathrm{mM}$ concentrations and solution thermal stability upon heating to $95{ }^{\circ} \mathrm{C}$ was excellent. Due to the problems with aggregation at higher conncentrations, UV/vis titration experiments were not used to calculate binding parameters and are not presented. Molar extinction coefficients are given in Table 2.

Table 2. Absorption maxima and molar extinction coefficients of the dyes

\begin{tabular}{ccc}
\hline Dye & $\lambda_{\max }(\mathbf{n m})$ & $\boldsymbol{\varepsilon}\left(\mathbf{d m}^{-3} \mathbf{m o l}^{-1} \mathbf{c m}^{-\mathbf{1}}\right)$ \\
\hline A & 482 & $8.55 \times 10^{4}$ \\
B1 & 482 & $7.49 \times 10^{4}$ \\
B2 & 482 & $9.17 \times 10^{4}$ \\
C & 452 & $8.22 \times 10^{4}$ \\
\hline
\end{tabular}


Accepted manuscript - postprint version. Final form is published in: Kurutos, A., Orehovec, I., Saftić, D., Horvat, L., Crnolatac, I., Piantanida, I., \& Deligeorgiev, T. (2018). Cell penetrating, mitochondria targeting multiply charged DABCO-cyanine dyes. Dyes and Pigments, 158, 517-525.

https://doi.org/10.1016/j.dyepig.2018.05.035

Dye solutions in buffer exhibit negligible fluorescence emission, however upon addition of DNA/RNA the emission intensity increases dramatically, as shown in the figure 3 and supp. info. The increase of the fluorescence intensity upon planarization and rigidification of carbocyanines, due to DNA/RNA binding is well documented and studied phenomena [35, 36]. In short, by binding with biomacromolecules, cyanine dye loses the freedom of torsional motion around the methine bridge which is the main mode of nonradiative decay of the free dye molecule in the excited state. Thus, instead of losing absorbed energy through such nonradiative process, the bound dye shows increased emission quantum yield [37, 38].

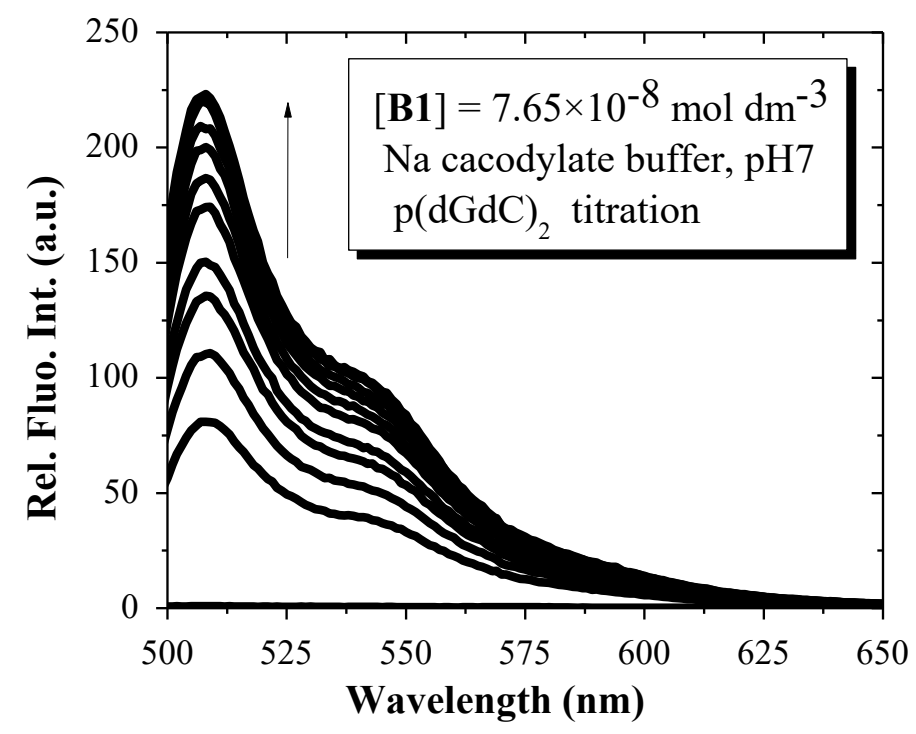

Figure 2. Changes in fluorescence spectrum of B1 $\left(c=7.65 \times 10^{-8} \mathrm{~mol} \mathrm{dm}^{-3}\right)$ upon titration with $\mathrm{p}(\mathrm{dGdC})_{2}$

Therefore, the intensity of fluorescence response upon DNA/RNA binding depends on number of different factors such as: the dye structure (absorption, Table 2), but even more so on the mode of binding (intercalation, groove binding or electrostatic interaction), magnitude of the interaction (represented by $K_{d}$ or $K_{s}$ ), the differences between DNA/RNA secondary motifs, groove geometry (Table S3, Supp. info) and the local micro-environment at the binding site. 
Accepted manuscript - postprint version. Final form is published in: Kurutos, A., Orehovec, I., Saftić, D., Horvat, L., Crnolatac, I., Piantanida, I., \& Deligeorgiev, T. (2018). Cell penetrating, mitochondria targeting multiply charged DABCO-cyanine dyes. Dyes and Pigments, 158, 517-525.

https://doi.org/10.1016/j.dyepig.2018.05.035

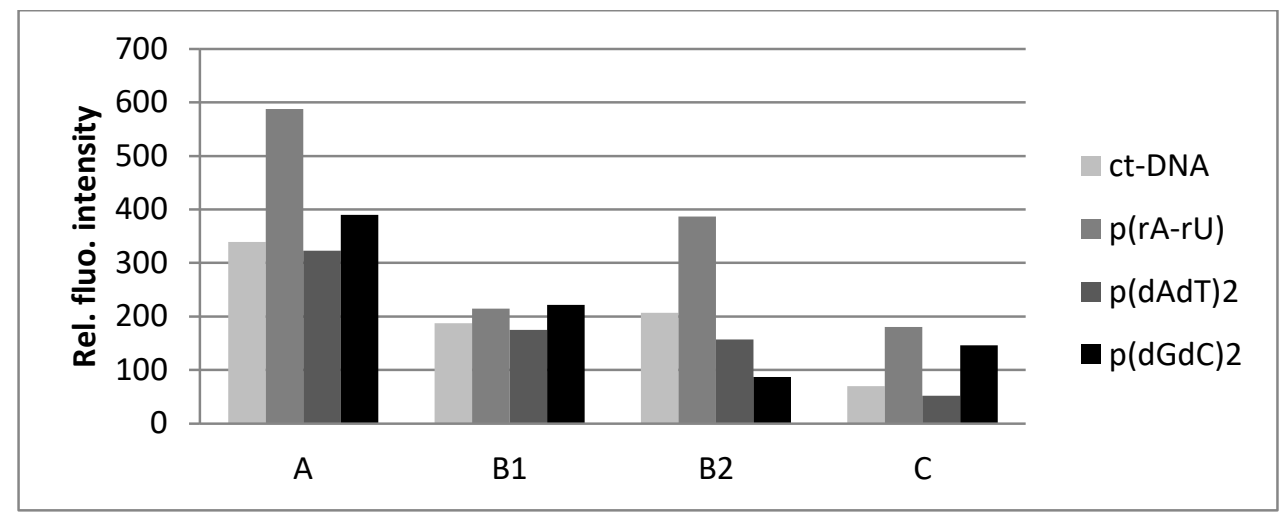

Figure 3. The increase of the fluorescence intensity upon addition of the polynucleotide (ct-DNA, pApU, $\mathrm{p}(\mathrm{dAdT})_{2}$ and $\left.\mathrm{p}(\mathrm{dGdC})_{2}\right)$ to the dye solutions $\left(\mathrm{c}=1 \times 10^{-7} \mathrm{~mol} \mathrm{dm}^{-3}\right.$ in $50 \mathrm{mM}$ Na cacodylate, $\left.\mathrm{pH} 7\right)$. The increase was calculated by subtraction of the intrinsic dye fluorescence intensity from the maximal measured intensity of the formed complex [bound dye/polynucleotide], upon saturation of the binding sites.

As a result, the prediction of the fluorescence response is never straightforward and correlating it individually to any one of these factors is not possible.

To further evaluate the mode of interaction and gain more structural information on the resulting dye-polynucleotide complex, we used CD spectropolarimetry (Figure 4, supp. info.), sensitive method for the elucidation of conformational changes in the secondary structure of polynucleotides [39]. Also, the dye-DNA/RNA complex often shows induced (I)CD band coinciding with the UV/Vis absorption band of the dye, which in this case is far from the CD bands of DNA/RNA. The appearance, sign and magnitude of such bands provides information on the binding mode (intercalation, groove binding, agglomeration, etc.) [40].
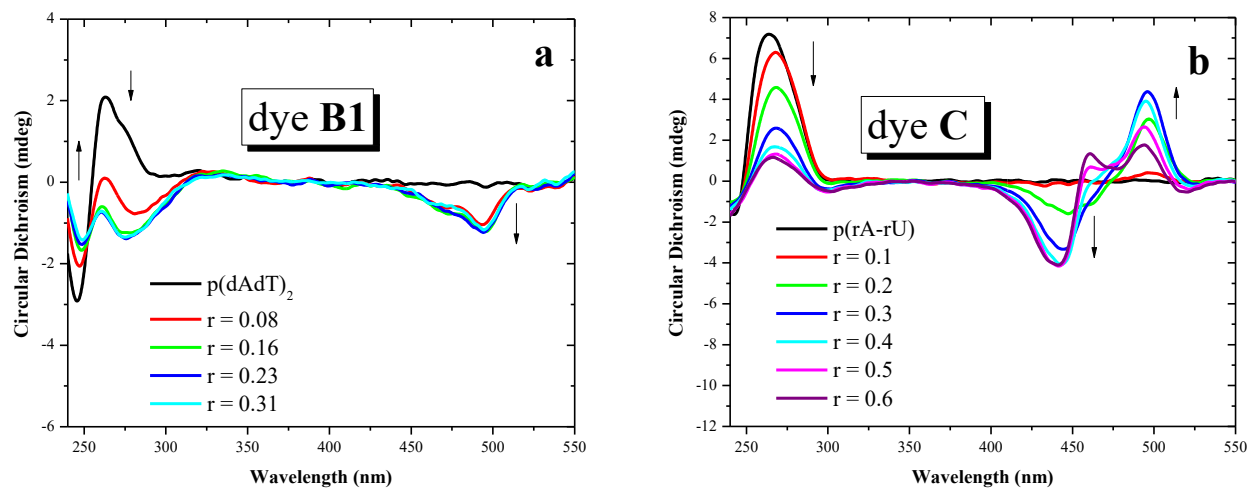
Accepted manuscript - postprint version. Final form is published in: Kurutos, A., Orehovec, I., Saftić, D., Horvat, L., Crnolatac, I., Piantanida, I., \& Deligeorgiev, T. (2018). Cell penetrating, mitochondria targeting multiply charged DABCO-cyanine dyes. Dyes and Pigments, 158, 517-525.

https://doi.org/10.1016/j.dyepig.2018.05.035

Figure 4. CD titration of a) $\mathrm{p}(\mathrm{dAdT})_{2}\left(c=2 \times 10^{-5} \mathrm{~mol} \mathrm{dm}^{-3}\right)$, b) $\mathrm{p}(\mathrm{rA}-\mathrm{rU})\left(c=2 \times 10^{-5} \mathrm{~mol} \mathrm{dm}^{-3}\right)$, with a) B1; b) C at molar ratios $r=$ [compound] / [nucleotide] (pH 7.0, buffer sodium cacodylate, $I=0.05 \mathrm{~mol} \mathrm{dm}^{-3}$ ).

Considering that the DNA/RNA CD bands $(230-290 \mathrm{~nm})$ coincide with the absorption bands of the dyes (supp. info), the changes in those bands, induced by the addition of dyes could appear as a result of the changes in the DNA/RNA secondary structure or as a ICD signal of a complex. Therefore the mode of binding could only be elucidated from the appearance of ICD bands at 450-550 nm. Addition of A, B1, B2 and C dyes to ds-DNA resulted in negative ICD band within $450-550 \mathrm{~nm}$ range, characteristic for the intercalative binding mode (Figure 4a, Supp. Info). At higher ratios $r(r>0.3)$ dye is in the excess with respect to the intercalative binding sites, according to the "neighbour exclusion principle" [41]. Thus the saturation of the intercalative binding sites could be observed even at lower ratios, represented by the absence of changes in the ICD bands. On the other hand, upon addition of dyes to ds-RNA solution, binding event represented by bisignate CD signals at 450-550 nm can be observed (Figure 4b, Supp. info), which indicates excitonic coupling of dye aggregates [35]. After meticulous examination it can be observed that at lower ratios $(\mathrm{r}=$ 0.1 , there is only slight positive ICD signal, the bisignate ICD appears only after more dye has been added. This strongly signifies two different binding modes; first occuring at lower ratios is followed by dimerization or higher scale aggregation within the ds-RNA groove, most probably major groove, due to the unfavoured geometry of the minor groove (Table S3, Supp. Info).

Although, binding parameters (stability constant $K_{s}$; stoichiometric binding ratio $N$ ) can be calculated from the fluorimetric titration data, we used calorimetric titrations (ITC) to evaluate binding of the dyes with DNA/RNA. Above mentioned binding parameters along with the thermodynamic properties of the binding process $\left(\Delta_{r} H, \Delta_{r} G\right.$, and $\left.-T \Delta_{r} S\right)$ are presented in the Table 4. Calorimetric titration of ds-DNA/RNA sequences (mixed sequence-ctDNA, 
Accepted manuscript - postprint version. Final form is published in: Kurutos, A., Orehovec, I., Saftić, D., Horvat, L., Crnolatac, I., Piantanida, I., \& Deligeorgiev, T. (2018). Cell penetrating, mitochondria targeting multiply charged DABCO-cyanine dyes. Dyes and Pigments, 158, 517-525.

https://doi.org/10.1016/j.dyepig.2018.05.035

alternating AT and GC, homopolymer rArU sequences) with the studied compounds revealed comparable stability constants $\left(K_{s}\right)$, with somewhat higher affinity for DNA/RNA binding of A (Figure 5).

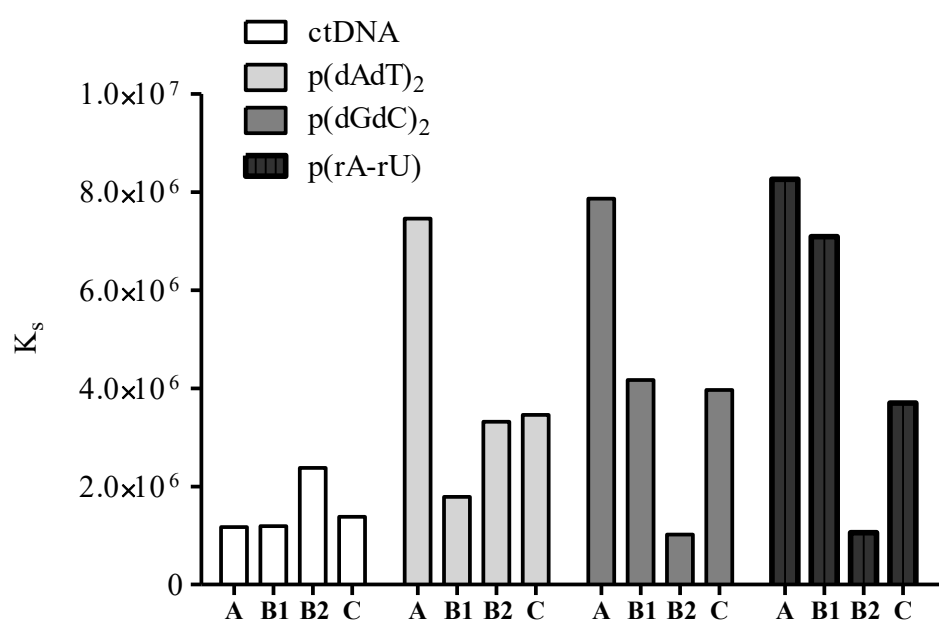

Figure 5. The stability constants $\left(K_{s}\right)$ obtained by ITC, using specific models and Origin 7.5 software

The binding isotherms (Figure 6, supp. info), indicate that in the case of binding of B1 and $\mathbf{C}$ to $\mathrm{p}(\mathrm{dAdT})_{2}$ there are two independent binding sites. The first binding process, that occurs when the dye molecules are scarce (lower $N$ ratios) is characterised by high enthalpic contribution to the free Gibbs energy $\Delta_{r} G$ and adverse entropic contribution (Table 4). Such combination usually indicates intercalative binding [42]. The interaction that drives intercalation, $\pi-\pi$ stacking results in high enthalpic contribution, while loss of freedom of motion results in decrease of enthropy and therefore works against free energy. 
Accepted manuscript - postprint version. Final form is published in: Kurutos, A., Orehovec, I., Saftić, D., Horvat, L., Crnolatac, I., Piantanida, I., \& Deligeorgiev, T. (2018). Cell penetrating, mitochondria targeting multiply charged DABCO-cyanine dyes. Dyes and Pigments, 158, 517-525.

https://doi.org/10.1016/j.dyepig.2018.05.035
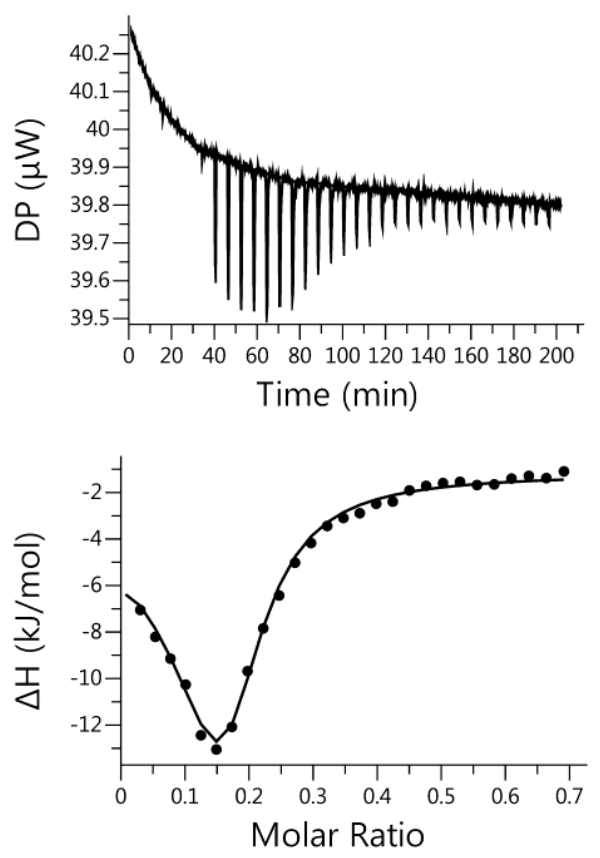

Figure 6. Final figure of the ITC titration of $\left.\mathrm{p}(\mathrm{dAdT})_{2}\left(c=3.00 \times 10^{-5} \mathrm{~mol} \mathrm{dm}^{-3}\right)\right)$ with $\mathbf{C}\left(c=1 \times 10^{-4} \mathrm{~mol} \mathrm{dm}^{-3}\right)$ in $50 \mathrm{mM}$ Na-cacodylate buffer, $\mathrm{pH} 7.00$ at $25^{\circ} \mathrm{C}$. Raw data above, calculated binding isotherm bellow.

The entropic contribution to $\Delta_{r} G$ is related to non-specific hydrophobic interaction, displacement of water molecules hydrophobic pockets, such as DNA/RNA grooves [43]. So the second binding incident has thermodynamic signature of groove binding. The enthropic contribution drives binding process with RNA sequence. With the exception of compound $\mathbf{A}$ which again shows two independent binding sites, with second one showing all the signs of groove binding and first has a thermodynamic signature of intercalation.

Table 4 Binding parameters and thermodynamic properties of the binding process from ITC titrations

\begin{tabular}{|c|c|c|c|c|c|c|c|c|c|c|c|}
\hline & $\begin{array}{c}{[\text { Cell] }} \\
\left(\mathbf{m o l ~ d m}^{-3}\right) \\
\end{array}$ & $\begin{array}{c}N \\
\text { (sites) } \\
\end{array}$ & $\begin{array}{c}K s \\
\left(\mathbf{m o l}^{-1} \mathbf{d m}^{3}\right) \\
\end{array}$ & $\begin{array}{c}\Delta_{r} H \\
(\mathbf{k J} / \mathbf{m o l}) \\
\end{array}$ & $\begin{array}{c}\Delta_{r} G \\
(\mathbf{k J} / \mathbf{m o l}) \\
\end{array}$ & $\begin{array}{c}-\mathrm{T} \Delta_{\Delta} S \\
(\mathrm{~kJ} / \mathrm{mol}) \\
\end{array}$ & $\begin{array}{c}N_{2} \\
\text { (sites) }\end{array}$ & $\begin{array}{c}K s_{2} \\
\left(\mathrm{~mol} \mathrm{dm}^{-3}\right) \\
\end{array}$ & $\begin{array}{c}\Delta_{r} H_{2} \\
(\mathbf{k J} / \mathbf{m o l})\end{array}$ & $\begin{array}{c}\Delta_{r} G_{2} \\
(\mathbf{k J} / \mathbf{m o l}) \\
\end{array}$ & $\begin{array}{c}-\mathrm{T} \Delta_{i} S_{2} \\
(\mathrm{~kJ} / \mathrm{mol}) \\
\end{array}$ \\
\hline $\mathbf{A}-\mathrm{p}(\mathrm{dAdT})_{2}$ & $3.14 \times 10^{-5}$ & 0.15 & $7.46 \times 10^{6}$ & -9.69 & -39.3 & -29.6 & - & - & - & - & - \\
\hline A-ctDNA & $3.14 \times 10^{-5}$ & 0.213 & $1.17 \times 10^{6}$ & -14.5 & -34.6 & -20.2 & - & - & - & - & - \\
\hline $\mathbf{A}-\mathrm{p}(\mathrm{dGdC})_{2}$ & $3.15 \times 10^{-5}$ & 0.181 & $7.87 \times 10^{6}$ & -17.6 & -39.4 & -21.8 & & & & & \\
\hline \multirow[t]{2}{*}{ A-p(rA-rU) } & $3.83 \times 10^{-5}$ & 0.139 & $1.54 \times 10^{7}$ & -256 & -41.1 & 215 & 0.1 & $1.62 \times 10^{7}$ & 321 & -41.2 & -362 \\
\hline & $\begin{array}{c}{[\text { Cell] }} \\
\left(\mathbf{m o l ~ d m}^{-3}\right) \\
\end{array}$ & $\begin{array}{c}N \\
\text { (sites) } \\
\end{array}$ & $\begin{array}{c}K s \\
\left(\mathbf{m o l}^{-1} \mathbf{d m}^{3}\right) \\
\end{array}$ & $\begin{array}{c}\Delta_{r} H \\
(\mathbf{k J} / \mathbf{m o l}) \\
\end{array}$ & $\begin{array}{c}\Delta_{r} G \\
(\mathbf{k J} / \mathbf{m o l}) \\
\end{array}$ & $\begin{array}{c}-\mathrm{T} \Delta_{\Delta} S \\
(\mathrm{~kJ} / \mathrm{mol}) \\
\end{array}$ & $\begin{array}{c}N_{2} \\
\text { (sites) }\end{array}$ & $\begin{array}{c}\begin{array}{c}K s_{2} \\
\left(\mathrm{~mol} \mathrm{dm}^{-3}\right)\end{array} \\
\end{array}$ & $\begin{array}{c}\Delta_{r} H_{2} \\
(\mathrm{~kJ} / \mathbf{m o l})\end{array}$ & $\begin{array}{c}\Delta_{r} G_{2} \\
(\mathbf{k J} / \mathbf{m o l}) \\
\end{array}$ & $\begin{array}{c}-\mathrm{T} \Delta_{H} S_{2} \\
(\mathrm{~kJ} / \mathrm{mol}) \\
\end{array}$ \\
\hline B1- $\left.\mathrm{p}(\mathrm{dAdT})_{2}\right)$ & $2.20 \times 10^{-5}$ & 0.034 & $4.08 \times 10^{5}$ & -82.4 & -32 & 50.3 & 0.244 & $1.79 \times 10^{6}$ & -2.63 & -35.7 & -33.1 \\
\hline
\end{tabular}


Accepted manuscript - postprint version. Final form is published in: Kurutos, A., Orehovec, I., Saftić, D., Horvat, L., Crnolatac, I., Piantanida, I., \& Deligeorgiev, T. (2018). Cell penetrating, mitochondria targeting multiply charged DABCO-cyanine dyes. Dyes and Pigments, 158, 517-525.

https://doi.org/10.1016/j.dyepig.2018.05.035

\begin{tabular}{|c|c|c|c|c|c|c|c|c|c|c|c|}
\hline B1-ctDNA & $3.40 \times 10^{-5}$ & 0.127 & $1.19 \times 10^{6}$ & -13.2 & -34.7 & -21.5 & - & - & - & - & - \\
\hline B1- $\mathrm{p}(\mathrm{dGdC})_{2}$ & $3.40 \times 10^{-5}$ & 0.208 & $4.17 \times 10^{6}$ & -15.5 & -37.8 & -22.3 & - & - & - & - & - \\
\hline \multirow[t]{2}{*}{ B1-p(rA-rU) } & $3.30 \times 10^{-5}$ & 0.434 & $7.09 \times 10^{6}$ & -9.89 & -39.1 & -29.2 & - & - & - & - & - \\
\hline & $\begin{array}{c}{[\text { Cell] }} \\
\left(\mathrm{mol} \mathrm{dm}^{-3}\right)\end{array}$ & $\begin{array}{c}N \\
\text { (sites) }\end{array}$ & $\begin{array}{c}K s \\
\left(\mathrm{~mol}^{-1} \mathrm{dm}^{3}\right) \\
\end{array}$ & $\begin{array}{c}\Delta_{r} H \\
(\mathbf{k J} / \mathbf{m o l}) \\
\end{array}$ & $\begin{array}{c}\Delta_{r} G \\
(\mathbf{k J} / \mathbf{m o l}) \\
\end{array}$ & $\begin{array}{c}-\mathrm{T} \Delta_{r} S \\
(\mathrm{~kJ} / \mathrm{mol}) \\
\end{array}$ & $\begin{array}{c}N_{2} \\
\text { (sites) }\end{array}$ & $\begin{array}{c}K s_{2} \\
\left.(\mathrm{~mol} \mathrm{dm})^{-3}\right)\end{array}$ & $\begin{array}{c}\Delta_{r} H_{2} \\
(\mathbf{k J} / \mathbf{m o l})\end{array}$ & $\begin{array}{c}\Delta_{r} G_{2} \\
(\mathbf{k J} / \mathbf{m o l})\end{array}$ & $\begin{array}{c}-\mathrm{T} \Delta_{h} S_{2} \\
(\mathrm{~kJ} / \mathrm{mol})\end{array}$ \\
\hline B2- $\mathrm{p}(\mathrm{dAdT})_{2}$ & $3.60 \times 10^{-5}$ & 0.17 & $3.32 \times 10^{6}$ & -14.8 & -37.3 & -22.4 & - & - & - & - & - \\
\hline B2-ctDNA & $3.00 \times 10^{-5}$ & 0.087 & $2.38 \times 10^{6}$ & -55.1 & -36.4 & 18.7 & - & - & - & - & - \\
\hline B2- $p(d G d C)_{2}$ & $3.00 \times 10^{-5}$ & 0.179 & $1.02 \times 10^{6}$ & -24.7 & -34.3 & -9.62 & - & - & - & - & - \\
\hline \multirow[t]{2}{*}{ B2-p(rA-rU) } & $7.40 \times 10^{-5}$ & 0.117 & $1.06 \times 10^{6}$ & -19.4 & -34.4 & -15 & - & - & - & - & - \\
\hline & $\begin{array}{c}{[\text { Cell] }} \\
\left(\mathrm{mol} \mathrm{dm}^{-3}\right) \\
\end{array}$ & $\begin{array}{c}N \\
\text { (sites) } \\
\end{array}$ & $\begin{array}{c}K s \\
\left(\mathrm{~mol}^{-1} \mathrm{dm}^{3}\right) \\
\end{array}$ & $\begin{array}{c}\Delta_{r} \boldsymbol{H} \\
(\mathrm{kJ} / \mathrm{mol}) \\
\end{array}$ & $\begin{array}{c}\Delta_{r} G \\
(\mathbf{k J} / \mathbf{m o l}) \\
\end{array}$ & $\begin{array}{c}-\mathrm{T} \Delta_{r} S \\
(\mathrm{~kJ} / \mathrm{mol}) \\
\end{array}$ & $\begin{array}{c}\mathrm{N}_{2} \\
\text { (sites) } \\
\end{array}$ & $\begin{array}{c}K s_{2} \\
\left(\mathrm{~mol} \mathrm{dm} \mathbf{d m}^{-3}\right) \\
\end{array}$ & $\begin{array}{c}\Delta_{r} H_{2} \\
(\mathbf{k J} / \mathbf{m o l}) \\
\end{array}$ & $\begin{array}{c}\Delta_{r} G_{2} \\
(\mathbf{k J} / \mathbf{m o l}) \\
\end{array}$ & $\begin{array}{c}-\mathrm{T} \Delta_{I} S_{2} \\
(\mathrm{~kJ} / \mathrm{mol}) \\
\end{array}$ \\
\hline C- $\mathrm{p}(\mathrm{dAdT})_{2}$ & $3.00 \times 10^{-5}$ & 0.037 & $1.10 \times 10^{6}$ & -67.2 & -34.5 & 32.7 & 0.159 & $3.46 \times 10^{6}$ & -0.733 & -37.4 & -36.6 \\
\hline C-ctDNA & $2.45 \times 10^{-5}$ & 0.141 & $1.38 \times 10^{6}$ & -21 & -35.1 & -14 & - & - & - & - & - \\
\hline C- $\mathrm{p}(\mathrm{dGdC})_{2}$ & $3.00 \times 10^{-5}$ & 0.163 & $3.97 \times 10^{6}$ & -23.8 & -37.7 & -13.9 & - & - & - & - & - \\
\hline C-p(rA-rU) & $3.60 \times 10^{-5}$ & 0.297 & $3.73 \times 10^{6}$ & -13.8 & -37.5 & -23.7 & - & - & - & - & - \\
\hline
\end{tabular}

\subsection{Biological activity, cellular uptake and distribution}

We tested A, B1, B2 and $\mathbf{C}$ for their antiproliferative activity against human tumour cell line $\mathbf{H 4 6 0}$ (Table 5). The compounds showed considerable antiproliferative effect after 3 days of incubation at concentrations exceeding $10^{-5} \mathrm{~mol} \mathrm{dm}^{-3}$ (Table 5). Therefore, to assess their subcellular localisation in $\mathbf{H 4 6 0}$ cell line, we used "safe" $10^{-6} \mathrm{~mol} \times \mathrm{dm}^{-3}$ concentration for the confocal microscopy live cell imaging experiment. After initial screening, we performed colocalisation study to confirm the cellular accumulation of the dyes. We used MitoTracker ${ }^{\mathrm{TM}}$ Deep Red FM (MitoTracker, ThermoFisher Scientific) as a mitochondrial probe and Hoechst 34580 (Hoechst, Sigma Aldrich) for the staining of nuclei.

Table $5 \mathrm{IG}_{50}$ values, compound concentrations leading to cellular viability reduction by $50 \%$, compared to the control.

\begin{tabular}{|c|c|c|c|c|}
\hline Dye & $\mathbf{A}$ & B1 & B2 & $\mathbf{C}$ \\
\hline $\mathrm{IG}_{50}\left(\mathrm{~mol} \times \mathrm{dm}^{-3}\right)$ & $6.86 \times 10^{-5}$ & $1.25 \mathrm{E} \times 10^{-4}$ & $2.3 \times 10^{-5}$ & $7.25 \times 10^{-5}$ \\
\hline
\end{tabular}


Accepted manuscript - postprint version. Final form is published in: Kurutos, A., Orehovec, I., Saftić, D., Horvat, L., Crnolatac, I., Piantanida, I., \& Deligeorgiev, T. (2018). Cell penetrating, mitochondria targeting multiply charged DABCO-cyanine dyes. Dyes and Pigments, 158, 517-525.

https://doi.org/10.1016/j.dyepig.2018.05.035

Cells were incubated with the compounds for $2 \mathrm{~h}$ prior to confocal microscopy, allowing enough time to enter the cell and reach their preferred subcellular location. Considering their structural similarity, relatively similar interaction with the DNA/RNA and similar antiproliferative activity, their faith after cell access is remarkably different. The $\mathbf{A}$ and $\mathbf{B 1}$ dyes enter the cell and target mitochondria, showing excellent denotation of those organelles, B2 marks nucleoli, while $\mathrm{C}$ seems not able to cross the cellular membrane or its fluorescence response is somehow quenched (Figure 7). The co-localization with the commercially available probes was used to verify these claims. MitoTracker $(c=200 \mathrm{nM})$ was added 30 min prior to visualisation, Hoechst was added $10 \mathrm{~min}$ before confocal microscopy. To excite the compounds A, B1 and $\mathbf{B} 2$ we used $482 \mathrm{~nm}$ laser line, and the emission was collected with a band pass detector $498-535 \mathrm{~nm}$. Compound $\mathbf{C}$ was excited at $452 \mathrm{~nm}$ and emission was set to $499-547 \mathrm{~nm}$. The excitation wavelength for the MitoTracker was set to $647 \mathrm{~nm}$, emission was captured at $670-712 \mathrm{~nm}$ and Hoechst was excited at $405 \mathrm{~nm}$, emission at $420-469 \mathrm{~nm}$. Co-localization of the compounds and the probes was confirmed by overlaying the photomicrographs of the A, B1 vs. MitoTracker channels of the same specimen and B2 vs. Hoechst 33342 (Figure 8, 9, 10).
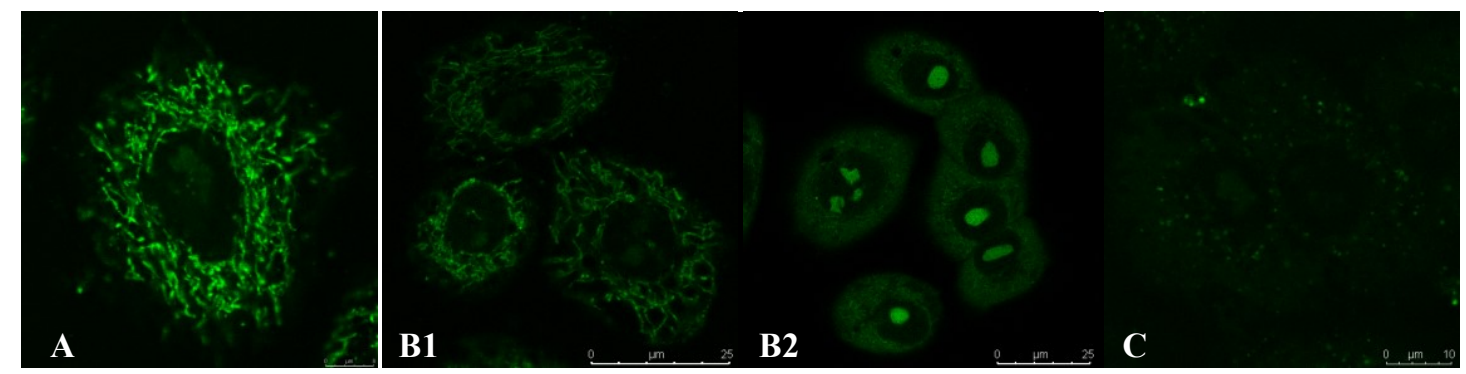

Figure 7. Confocal photomicrographs of live $\mathrm{H} 460$ cells after incubation with $1 \times 10^{-6} \mathrm{~mol} \mathrm{dm}^{-3}$ of A, B1, B2 and $\mathbf{C}$ dyes. 
Accepted manuscript - postprint version. Final form is published in: Kurutos, A., Orehovec, I., Saftić, D., Horvat, L., Crnolatac, I., Piantanida, I., \& Deligeorgiev, T. (2018). Cell penetrating, mitochondria targeting multiply charged DABCO-cyanine dyes. Dyes and Pigments, 158, 517-525.

https://doi.org/10.1016/j.dyepig.2018.05.035

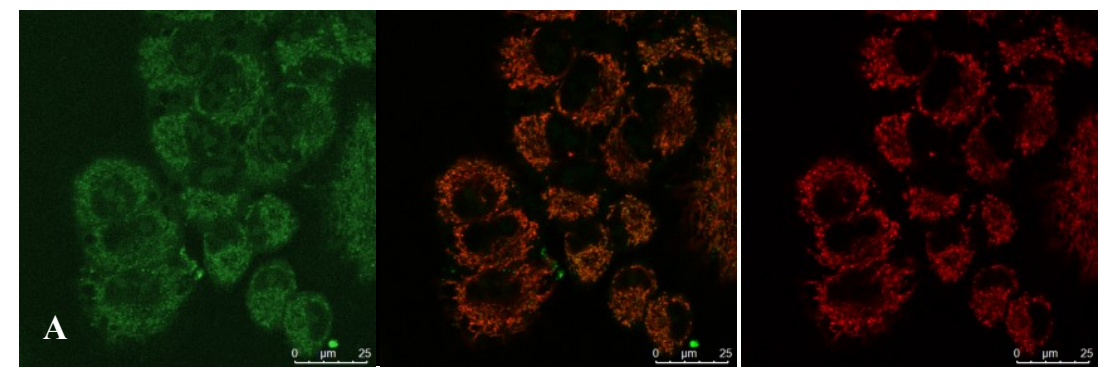

Figure 8. Confocal photomicrographs of live $\mathrm{H} 460$ cells after incubation with $1 \times 10^{-6} \mathrm{~mol} \mathrm{dm}^{-3}$ of $\mathbf{A}$ and $0.2 \times 10^{-6} \mathrm{~mol} \mathrm{dm}{ }^{-3}$ MitoTracker probe, LEFT: A channel, green; RIGHT: MitoTracker channel, red; MIDDLE: Overlay of the two channels.

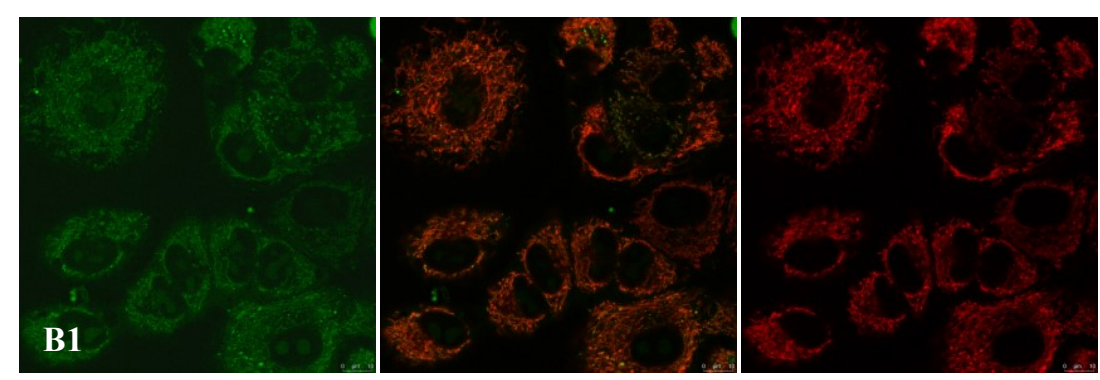

Figure 9. Confocal photomicrographs of live $\mathrm{H} 460$ cells after incubation with $1 \times 10^{-6} \mathrm{~mol} \mathrm{dm}^{-3}$ of $\mathbf{B} 1$ and $0.2 \times 10^{-6} \mathrm{~mol} \mathrm{dm}^{-3}$ MitoTracker probe, LEFT: B1 channel, green; RIGHT: MitoTracker channel, red; MIDDLE: Overlay of the two channels.
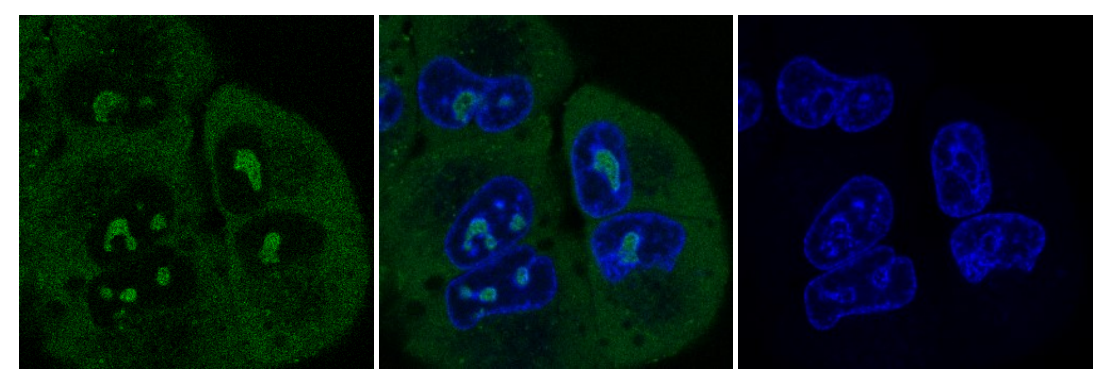

Figure 10. Confocal photomicrographs of live $\mathrm{H} 460$ cells after incubation with $1 \times 10^{-6} \mathrm{~mol} \mathrm{dm}^{-3}$ of $\mathbf{B 2}$ and $0.5 \times 10^{-6} \mathrm{~mol} \mathrm{dm}{ }^{-3}$ Hoechst probe, LEFT: B2 channel, green; RIGHT: Hoechst channel, blue; MIDDLE: Overlay of the two channels.

\section{Conclusions}

The A, B1, B2 and $\mathbf{C}$ dyes bind with high affinity to ds-DNA/RNA. The dyes predominantly intercalate into ds-DNAs, but also exhibit certain secondary binding event with alternating AT sequences. From CD titrations assessment we can conclude that the ds-RNA 
Accepted manuscript - postprint version. Final form is published in: Kurutos, A., Orehovec, I., Saftić, D., Horvat, L., Crnolatac, I., Piantanida, I., \& Deligeorgiev, T. (2018). Cell penetrating, mitochondria targeting multiply charged DABCO-cyanine dyes. Dyes and Pigments, 158, 517-525.

https://doi.org/10.1016/j.dyepig.2018.05.035

binding site could be major groove, where dyes form aggregates, most probably dimers [40]. As mentioned in the discussion, fluorimetric response of the dye-polynucleotide complexes depends on the number of parameters, and therefore too complex to control and predict, however compound A shows highest fluorescence increase upon interaction with the DNA/RNA. Even though they interact strongly with biomacromolecules, their influence on the proliferation of cells is not so prominent. Only at high concentrations $\left(10^{-5} \mathrm{M}\right.$ or higher),

after 3 days the compounds hamper the proliferation to $50 \%$ compared to the control. With the exception of $\mathbf{C}$, the dyes enter the cell and accumulate within the mitochondrial space (A and B1) or in the nucleoli (B2). Noteworthy, compound B2 also shows highest antiproliferation potential, as its subcellular target seems to be DNA rich nucleus. Brilliant fluorescence denotation of the mitochondria even at low concentrations of $\mathbf{A}$ and $\mathbf{B 1}$ dyes, absence of photobleaching effect and relative safety for the cell homeostasis, marks this two dyes as promising fluorescent markers for live cell imaging. Our previous live cell fluorescent imaging dyes $[18,19]$ were also based on oxazole yellow or thiazole orange scaffold bearing usually two positive charges. We added multiple charges to increase the water solubility and selectively accumulate the compounds in the mitochondria, while the other substituents were designed to keep the impact on cell proliferation minimal. Accumulation of compounds with such high charge density in intracellular space is not common and will be further explored in comparative studies.

\section{Acknowledgements}

AK is grateful for the financial support by the National Science Fund of Bulgarian Ministry of Education and Science under grant - contract № DM09/5 from 17.12.2016. IO, DS. IC and IP gratefully acknowledge financial support of Croatian Science Foundation Grant No 1477: DNA/RNA-MolSense. The authors extend their gratitude towards the staff of the Laboratory 
Accepted manuscript - postprint version. Final form is published in: Kurutos, A., Orehovec, I., Saftić, D., Horvat, L., Crnolatac, I., Piantanida, I., \& Deligeorgiev, T. (2018). Cell penetrating, mitochondria targeting multiply charged DABCO-cyanine dyes. Dyes and Pigments, 158, 517-525.

https://doi.org/10.1016/j.dyepig.2018.05.035

for mitochondrial bioenergetics and diabetes, Division of Molecular Medicine, Ruđer

Bošković Institute for their help and kind donations of the MitoTracker and Hoechst dyes.

\section{References}

[1] G. Bischoff, S. Hoffmann, DNA-binding of drugs used in medicinal therapies, Curr Med Chem, 9 (2002) 321-348.

[2] U. Pindur, M. Jansen, T. Lemster, Advances in DNA-ligands with groove binding, intercalating and/or alkylating activity: Chemistry, DNA-binding and biology, Curr Med Chem, 12 (2005) 2805-2847.

[3] M. Rask-Andersen, M.S. Almen, H.B. Schioth, Trends in the exploitation of novel drug targets, Nat Rev Drug Discov, 10 (2011) 579-590.

[4] A. Kurutos, O. Ryzhova, V. Trusova, G. Gorbenko, N. Gadjev, T. Deligeorgiev, Symmetric Meso-ChloroSubstituted Pentamethine Cyanine Dyes Containing Benzothiazolyl/Benzoselenazolyl Chromophores Novel Synthetic Approach and Studies on Photophysical Properties upon Interaction with bio-Objects, J Fluoresc, 26 (2016) 177-187.

[5] A. Kurutos, O. Ryzhova, V. Trusova, U. Tarabara, G. Gorbenko, N. Gadjev, T. Deligeorgiev, Novel asymmetric monomethine cyanine dyes derived from sulfobetaine benzothiazolium moiety as potential fluorescent dyes for non-covalent labeling of DNA, Dyes Pigments, 130 (2016) 122-128.

[6] A.K. Tewari, R. Dubey, Emerging trends in molecular recognition: Utility of weak aromatic interactions, Bioorgan Med Chem, 16 (2008) 126-143.

[7] B.A.D. Neto, J.R. Correa, R.G. Silva, Selective mitochondrial staining with small fluorescent probes: importance, design, synthesis, challenges and trends for new markers, Rsc Adv, 3 (2013) 5291-5301.

[8] M.P. Murphy, Targeting lipophilic cations to mitochondria, Bba-Bioenergetics, 1777 (2008) 1028-1031.

[9] S.W. Perry, J.P. Norman, J. Barbieri, E.B. Brown, H.A. Gelbard, Mitochondrial membrane potential probes and the proton gradient: a practical usage guide, Biotechniques, 50 (2011) 98-115.

[10] S. Dhamgaye, F. Devaux, R. Manoharlal, P. Vandeputte, A.H. Shah, A. Singh, C. Blugeon, D. Sanglard, R. Prasad, In Vitro Effect of Malachite Green on Candida albicans Involves Multiple Pathways and Transcriptional Regulators UPC2 and STP2, Antimicrob Agents Ch, 56 (2012) 495-506.

[11] T. Minamikawa, A. Sriratana, D.A. Williams, D.N. Bowser, J.S. Hill, P. Nagley, Chloromethyl-X-rosamine (MitoTracker Red) photosensitises mitochondria and induces apoptosis in intact human cells, J Cell Sci, 112 (1999) 2419-2430.

[12] D.G. Nicholls, M.W. Ward, Mitochondrial membrane potential and neuronal glutamate excitotoxicity: mortality and millivolts, Trends Neurosci, 23 (2000) 166-174.

[13] S.W. Perry, J.P. Norman, J. Barbieri, E.B. Brown, H.A. Gelbard, Mitochondrial membrane potential probes and the proton gradient: a practical usage guide, Biotechniques, 50 (2011) 98-+.

[14] H. Rottenberg, S.L. Wu, Quantitative assay by flow cytometry of the mitochondrial membrane potential in intact cells, Bba-Mol Cell Res, 1404 (1998) 393-404.

[15] J.R. Bunting, A Test of the Singlet Oxygen Mechanism of Cationic Dye Photosensitization of Mitochondrial Damage, Photochem Photobiol, 55 (1992) 81-87.

[16] T. Takizawa, J.M. Robinson, Analysis of antiphotobleaching reagents for use with fluoroNanogold in correlative microscopy, J Histochem Cytochem, 48 (2000) 433-436.

[17] I. Crnolatac, L.M. Tumir, N.Y. Lesev, A.A. Vasilev, T.G. Deligeorgiev, K. Miskovic, L. Glavas-Obrovac, O. Vugrek, I. Piantanida, Probing the Structural Properties of DNA/RNA Grooves with Sterically Restricted Phosphonium Dyes: Screening of Dye Cytotoxicity and Uptake, Chemmedchem, 8 (2013) 1093-1103.

[18] A. Kurutos, I. Orehovec, A.T. Paic, I. Crnolatac, L. Horvat, N. Gadjev, I. Piantanida, T. Deligeorgiev, New series of non-toxic DNA intercalators, mitochondria targeting fluorescent dyes, Dyes Pigments, 148 (2018) 452 459. 
Accepted manuscript - postprint version. Final form is published in: Kurutos, A., Orehovec, I., Saftić, D., Horvat, L., Crnolatac, I., Piantanida, I., \& Deligeorgiev, T. (2018). Cell penetrating, mitochondria targeting multiply charged DABCO-cyanine dyes. Dyes and Pigments, 158, 517-525.

https://doi.org/10.1016/j.dyepig.2018.05.035

[19] A. Saric, I. Crnolatac, F. Bouillaud, S. Sobocanec, A.M. Mikecin, Z.M. Safranko, T. Delgeorgiev, I. Piantanida, T. Balog, P.X. Petit, Non-toxic fluorescent phosphonium probes to detect mitochondrial potential, Methods Appl Fluores, 5 (2017).

[20] S. Alunni, W.P. Jencks, Catalysis of the Reversible Elimination-Reactions of Substituted N-(BetaPhenylethyl)Quinuclidinium Ions in Aqueous-Solution, J Am Chem Soc, 102 (1980) 2052-2060.

[21] A.K.V. Bannerjee, L.M.; Quagliano J.V., The donor properties of positively charged ligands. Metal complexes of the n-alkyltriethylenediaminium cation, Coordination Chemistry Reviews, 1 (1966) 239-248.

[22] J.B. Higgins, K.D. Schmitt, ZSM-10: Synthesis and tetrahedral framework structure, Zeolites, 16 (1996) 236-244.

[23] T. Takewaki, L.W. Beck, M.E. Davis, Zeolite synthesis using 1,4-diazabicyclo[2,2,2]octane (DABCO) derivatives as structure-directing agents, Micropor Mesopor Mat, 33 (1999) 197-207.

[24] A.P.S. Gray, D.C.;Spinner, E.E.; Cavallito, C.J., The Preparation of Some ı-Bromoalkyl Quaternary Ammonium Salts, Journal of American Chemical Society, 77 (1955) 3648-3649.

[25] B.H. Beilenson, F.M., Preparation of simple cyanines, Journal of the Chemical Society (Resumed), 0 (1939) $143-151$.

[26] S.C. Benson, P. Singh, A.N. Glazer, Heterodimeric DNA-Binding Dyes Designed for Energy-Transfer Synthesis and Spectroscopic Properties, Nucleic Acids Res, 21 (1993) 5727-5735.

[27] T. Deligeorgiev, A. Vasilev, T. Tsvetkova, K.H. Drexhage, Synthesis of novel monomeric asymmetric triand tetracationic monomethine cyanine dyes as fluorescent non-covalent nucleic acid labels, Dyes Pigments, 75 (2007) 658-663.

[28] T.G. Deligeorgiev, A.A. Kurutos, N.I. Gadjev, A.A. Alexiev, An easy and fast one-pot preparation of 2thiomethyl and 2-thioacyl benzothiazoles, benzoxazoles, and benzimidazoles, Bulg Chem Commun, 47 (2015) 1034-1038.

[29] T.K. Deligeorgiev, A.; Gadjev, N., 1-(3-Iodopropyl)-4-methylquinolin-1-ium Iodide, Molbank, 2015 (2015) M874.

[30] A.G. Kurutos, N.; Šmidlehner, T.; Minkovska, S.; Piantanida, I.; Deligeorgiev, T., 2,3-

Dimethylbenzoxazolium Methosulfate, Molbank, 2016 (2016) M889.

[31] B.R. Rani, U.T. Bhalerao, M.F. Rahman, An Unusual S-Alkylation and N-Alkylation of Mercapto Substituted Heterocycles with O,O-Dialkyl Chlorophosphate/Thiophosphate, Synthetic Commun, 20 (1990) 3045-3052.

[32] H.S. Rye, S. Yue, D.E. Wemmer, M.A. Quesada, R.P. Haugland, R.A. Mathies, A.N. Glazer, Stable Fluorescent Complexes of Double-Stranded DNA with Bis-Intercalating Asymmetric Cyanine Dyes - Properties and Applications, Nucleic Acids Res, 20 (1992) 2803-2812.

[33] S.T.H. Yue, R.P., Dimers of unsymmetrical cyanine dyes containing pyridinium moieties, in, 1995.

[34] J.L. Bresloff, D.M. Crothers, Equilibrium Studies of Ethidium-Polynucleotide Interactions, BiochemistryUs, 20 (1981) 3547-3553.

[35] B.A. Armitage, Cyanine dye-DNA interactions: Intercalation, groove binding, and aggregation, DNA Binders and Related Subjects, 253 (2005) 55-76.

[36] J.R. Carreon, K.M. Stewart, K.P. Mahon, S. Shin, S.O. Kelley, Cyanine dye conjugates as probes for live cell imaging, Bioorg Med Chem Lett, 17 (2007) 5182-5185.

[37] T.L. Netzel, K. Nafisi, M. Zhao, J.R. Lenhard, I. Johnson, Base-content dependence of emission enhancements, quantum yields, and lifetimes for cyanine dyes bound to double-strand DNA: Photophysical properties of monomeric and bichromophoric DNA stains, J Phys Chem-Us, 99 (1995) 17936-17947. [38] G.L. Silva, V. Ediz, D. Yaron, B.A. Armitage, Experimental and computational investigation of unsymmetrical cyanine dyes: Understanding torsionally responsive fluorogenic dyes, J Am Chem Soc, 129 (2007) 5710-5718.

[39] A.N. Rodger, B., Circular Dichroism and Linear Dichroism, Oxford University Press, New York, 1997. [40] M. Eriksson, B. Norden, Linear and circular dichroism of drug-nucleic acid complexes, Method Enzymol, 340 (2001) 68-98.

[41] J. Cairns, The Application of Autoradiography to the Study of DNA Viruses, in: Cold Spring Harbour Symposia on Quantitative Biology, CSH Press, Cold Spring Harbour, 1962.

[42] J.B. Chaires, A thermodynamic signature for drug-DNA binding mode, Arch Biochem Biophys, 453 (2006) 26-31.

[43] M.L. McDermott, H. Vanselous, S.A. Corcelli, P.B. Petersen, DNA's Chiral Spine of Hydration, Acs Central Sci, 3 (2017) 708-714. 